\title{
Paclobutrazol Concentration and Substrate Moisture Status Impact Efficacy of Liner Dips for Size Control of Three Bedding Plants
}

\author{
Rebecca A. Schnelle ${ }^{1,3}$ and James E. Barrett ${ }^{2}$
}

ADDITIONAL INDEX WORDS. australian fanflower, impatiens, petunia, plant growth regulators, scaevola

SUMMARY. The influence of several environmental and cultural factors on the efficacy of paclobutrazol liner dips were evaluated for three species of bedding plants: 'Fancy' scaevola (Scaevola aemula), 'Suncatcher Plum' petunia (Petunia $\times$ bybrida), and 'Double Fiesta Rose' impatiens (Impatiens walleriana). The impact of paclobutrazol concentration in the dip solution, location of treatment, root substrate moisture status, and time in the dip solution were investigated. Before the liner dip application, the rooting substrate was brought to a specific percentage of container water capacity $(20 \%-100 \%)$. Liners were then dipped in a paclobutrazol solution of the prescribed concentration $\left(1-16 \mathrm{mg} \cdot \mathrm{L}^{-1}\right)$ for a prescribed time interval $(10-300 \mathrm{~s})$ in a specific location (open-wall greenhouse, polyethylene-glazed greenhouse under $\mathbf{8 0} \%$ shade fabric, three-wall potting shed, or building interior). Plant size data were collected when the untreated control plants reached a marketable stage. Paclobutrazol concentration and root substrate moisture status had a significant effect on size control, but location and dip duration did not. Size suppression varied by species. Following a liner dip at $2 \mathrm{mg} \cdot \mathrm{L}^{-1}$, scaevola, impatiens, and petunia plants were $44 \%$, $26 \%$, and $11 \%$ smaller than the untreated controls, respectively. Petunia plants dipped in a $8 \mathrm{mg} \cdot \mathrm{L}^{-1}$ paclobutrazol solution with substrate moisture status of $100 \%, 90 \%$, $80 \%, 70 \%, 50 \%$, or $20 \%$ of container capacity were $11 \%, 8 \%, 25 \%, 30 \%, 41 \%$, or $42 \%$ smaller than the untreated control, respectively (30 s dip duration, open-wall greenhouse). Petunia plants dipped in a solution of $8 \mathrm{mg} \cdot \mathrm{L}^{-1}$ paclobutrazol for 10,30 , 120 , or $300 \mathrm{~s}$ were all between $18 \%$ and $23 \%$ smaller than the control $(50 \%$ of container capacity, open-wall greenhouse). Petunia plants dipped in an $8 \mathrm{mg} \cdot \mathrm{L}^{-1}$ paclobutrazol solution in all four locations were all $20 \%$ to $21 \%$ smaller than the untreated control.

$\mathrm{D}$ eveloping a successful growth control program is one of the greatest challenges facing bedding plant producers. Many of the popular vegetatively propagated bedding plant species are highly vigorous and require plant growth regulator applications to achieve the accepted product form for retail sales in 4- to 5-inch-diameter containers.

Paclobutrazol is a widely used plant growth regulator for size control of commercially produced ornamental crops such as bedding plants,

This research was funded by the Florida Agricultural Experiment Station (FAES) and grant support was received from Chemtura.

Thanks to Caroline Bartuska for her technical support, SuperFresh for Scaevola cuttings, the Ball Horticultural company for petunia and impatiens unrooted cuttings, Fafard for the root substrate, and Scotts for the fertilizer.

The use of trade names in this publication does not imply endorsement by the FAES of products named nor criticism of similar ones not mentioned.

${ }^{1}$ Department of Horticulture, University of Kentucky, Lexington, KY 40546

${ }^{2}$ Department of Environmental Horticulture, University of Florida, Gainesville, FL 32611-0670

${ }^{3}$ Corresponding author. E-mail: Rebecca.schnelle@ uky.edu. bulb crops, herbaceous perennials, and flowering woody crops (Barrett and Nell, 1992; Gent, 2004; Gibson and Groninger, 2006; Ranwala et al., 2005; Starman and Williams, 2000). Paclobutrazol is highly active when applied as a foliar spray, drench, or subirrigation application (Barrett and Bartuska, 1982; Million et al., 1999).

Recent growth regulator research has reported that earlier applications such as treating substrate at planting, seed soaks, and bulb dips produce the desired response while allowing for more efficient chemical use (Barrett et al., 2003; Magnitskiy et al., 2006; Ranwala et al., 2005). The liner dip or soak is a technique for delivering the recommended early dose of plant growth regulators with specific protocols to maximize plant growth regulator efficacy. With this application technique, containerized rooted cuttings are dipped in a solution containing the desired concentration of growth regulator before transplant into the final container (Schnelle et al., 2005; Schnelle and Barrett, 2006). Whipker et al. (2000) reported effective control of scaevola in finished containers with 30 -s liner dips with 2 to $4 \mathrm{mg} \cdot \mathrm{L}^{-1}$ paclobutrazol solutions. Preliminary research on this technique reported variable size control following liner dips in solutions containing the same plant growth regulator concentration (Cerveny and Barrett, 2002). This led to the hypotheses that in addition to paclobutrazol concentration, dip duration, moisture status of the root substrate, and location of the treatment (indoors vs. outdoors) may impact the efficacy of a liner dip application (Schnelle et al., 2005; Schnelle and Barrett, 2006). This study was designed to test these hypotheses.

\section{Materials and methods}

General culture. Four experiments were designed to further investigate the impacts of these environmental and cultural factors on the efficacy of paclobutrazol liner dips. Three vegetatively propagated bedding plants were used: 'Suncatcher Plum' petunia, 'Double Fiesta Rose' impatiens, and 'Fancy' scaevola. Unrooted cuttings were obtained from commercial suppliers and were stuck individually into Ellepot cells (Blackmore Co., Belleville, MI). The Ellepot system is a preformed propagation cell that is composed of a peat- and perlite-based rooting substrate inside a woven fabric sleeve. The cells are placed in a plastic Ellepot tray that is formed to hold the individual cells and cuttings upright. Ellepot cells used in this study were $3 \mathrm{~cm}$ in diameter and $7 \mathrm{~cm}$ tall. Ellepots are marketed in metric sizes. Cuttings were rooted for 3 weeks under intermittent mist (10 s every $15 \mathrm{~min}$ ). At the end of the propagation period, dip treatments were applied to the rooted cuttings (liners) as described in the liner dip protocol. Rooted cuttings were then transplanted into 4.5inch-diameter containers containing

\begin{tabular}{llll}
\hline $\begin{array}{l}\text { Units } \\
\begin{array}{l}\text { To convert U.S. to SI, } \\
\text { multiply by }\end{array}\end{array}$ & U.S. unit & SI unit & $\begin{array}{l}\text { To convert SI to U.S., } \\
\text { multiply by }\end{array}$ \\
\hline 2.54 & inch(es) & $\mathrm{cm}$ & 0.3937 \\
28.3495 & $\mathrm{oz}$ & $\mathrm{g}$ & 0.0353 \\
1 & $\mathrm{ppm}$ & $\mathrm{mg} \cdot \mathrm{L}^{-1}$ & 1
\end{tabular}


growing substrate that consists of 6.5 sphagnum peat:2 perlite: 1.5 vermiculite (v/v; Fafard Number 2 medium; Conrad Fafard, Anderson, SC). Plants were subsequently grown on subirrigation benches in an open-wall greenhouse located in Gainesville, FL, under natural daylength conditions at ambient temperatures. Fertilization was delivered in the irrigation water containing nitrogen at $75 \mathrm{mg} \cdot \mathrm{L}^{-1}$ using $20 \mathrm{~N}-4.4 \mathrm{P}-16.6 \mathrm{~K}$ fertilizer (Peters 20-10-20; Scotts, Marysville, OH).

LINER DIP PROTOCOL. A rectangular tray was filled to a depth of 2 inches with paclobutrazol solution (Paczol; Chemtura, Middlebury, CT). An Ellepot tray cut to hold 10 rooted cuttings was placed in the solution for 30 s. After dipping, liners were placed on a bench and allowed to drain. Moisture status of the rooting substrate was $50 \%$ at time of dip treatment. Dip treatments occurred in the openwall greenhouse with photosynthically active radiation $(P A R)$ above 1330 $\mu \mathrm{mol} \cdot \mathrm{m}^{-2} \cdot \mathrm{s}^{-1}$, measured with a steadystate porometer (LI-1600; LI-COR, Lincoln, NE). All experiments were arranged in a randomized completeblock design with 10 single-plant replications of each treatment. Blocks were arranged across the greenhouse bench to identify any effect of microclimate on plant size. Block effects were not significant in each experiment, thus data were pooled.

Paclobutrazol concentraTION. A range of concentrations of paclobutrazol were applied in the liner dip to determine standard growth response curves for each of the bedding plant species. Scaevola cuttings were dipped in paclobutrazol solutions with a concentration of 0 , $0.5,1,2$, or $4 \mathrm{mg} \cdot \mathrm{L}^{-1}$ on $16 \mathrm{Feb}$., and data were collected on 7 Apr. Petunia and impatiens cuttings were dipped in $0,1,2,4,8$, or $16 \mathrm{mg} \cdot \mathrm{L}^{-1}$ paclobutrazol solutions. The treatments were applied on 16 Feb. and data were collected on 20 Mar. for petunia. For impatiens, treatments were done on 23 Mar., and data were collected on 25 Apr.

Treatment location. Commercial producers might perform the liner dip in a number of different types of facilities, and an experiment was conducted to evaluate the possibility that the type of facility in which the liner dip is administered might alter paclobutrazol efficacy on petunia liners.
The experiment was designed as a $3 \times 4$ factorial plus a single untreated control. The three paclobutrazol concentrations were 2,4 , and $8 \mathrm{mg} \cdot \mathrm{L}^{-1}$. The four environments were a building interior with florescent lighting, inside a three-wall potting shed with an opaque roof, under $80 \%$ shadecloth inside a polyethylene-glazed greenhouse, and in an open-wall greenhouse without additional shade. The light levels at treatment were 9.0, 21, 299, and $1330 \mu \mathrm{mol} \cdot \mathrm{m}^{-2} \cdot \mathrm{s}^{-1} P A R$, respectively. Liners were moved to the application location $24 \mathrm{~h}$ before dipping and remained there for $24 \mathrm{~h}$ following application. An untreated control group of cuttings was included in the openwall greenhouse location. The plants were treated on $23 \mathrm{Mar}$., and data were collected on 18 Apr.

Substrate moisture status. The moisture status of the rooting substrate at the time the dip is performed could affect the amount of chemical taken into the substrate and thus could be a source of variability of paclobutrazol efficacy in liner dip treatments. Moisture status was described as an approximate percentage of container water holding capacity by weight. The container capacity was determined by saturating 30 Ellepot cells in trays and allowing the excess water to drain before weighing the cells individually. The average weight of the cells at container capacity was considered to represent $100 \%$ of container capacity by weight. The cells were allowed to air dry for 1 week and were then weighed again. The average weight of the air-dried cells was deemed $0 \%$ of container capacity by weight. The average weights were multiplied by 10 and the weight of the tray was added to determine the weight required for a treatment group of liners (10 liners in a tray) to be at a desired container capacity. To achieve the desired substrate moisture status, the Ellepot cells were dried down to near the plants' wilting point and water was then added slowly by hand to bring the 10 cells in a tray to the calculated weight corresponding to the prescribed percentage of container capacity. On average, 10 Ellepot cells in a tray weighed $309 \mathrm{~g}$ at container capacity and $68 \mathrm{~g}$ when air-dried, indicating that $24 \mathrm{l} \mathrm{g}$ of water was held by the substrate. The weight of the rooted cuttings was negligible compared with the weight of the water held in the substrate. Liners were treated with an $8 \mathrm{mg} \cdot \mathrm{L}^{-1}$ paclobutrazol solution on 2 Aug. Root substrate moisture status was $100 \%, 90 \%, 80 \%, 70 \%, 50 \%$, or $20 \%$ of container capacity by weight as described above. Data were collected on 24 Aug.

Substrate moisture status AND DIP DURATION. The amount of time the liners are held in the paclobutrazol solution could potentially affect the efficacy of the treatment, and this experiment was conducted to determine how this dip duration and substrate moisture status might interact. Petunia liners were dipped in a paclobutrazol solution with a concentration of $8 \mathrm{mg} \cdot \mathrm{L}^{-1}$. The $3 \times 4$ factorial experiment used medium moisture statuses of $100 \%, 75 \%$, or $50 \%$ and dip durations of $10,30,120$, or $300 \mathrm{~s}$ with a single untreated control group. The application was on 2 Aug., and data were taken on 24 Aug.

Data collection. Data were collected when the plants reached marketability. Marketability was identified as the stage of development at which the control plants were in flower and the foliage covered the surface of the root substrate. Plant height (container rim to the highest growing point) and plant diameter (widest dimension and turned $90^{\circ}$, and averaged) were measured for petunia and impatiens. All measurements were taken in $\mathrm{cm}$. Plant size was calculated by the formula (height + average width) $\div 2$. Scaevola had a more prostrate growth habit; therefore, average lateral length was determined in place of a plant size. Average lateral length was calculated from the length of the three longest lateral stems arising from the main stem.

Data were analyzed with the general linear model (SAS, version 9.2; SAS Institute, Cary, NC). Means were separated by the Waller-Duncan Kratio $t$ test at $P \leq 0.05$. Plant size and lateral length values were regressed using the PROC REG procedure (SAS, version 9.2) to determine the best-fit linear or quadratic model for paclobutrazol liner dips. Terms of the model were judged to be significant or nonsignificant and were included in the final model based on a comparison of $\mathrm{F}$ values at $P \leq 0.05$.

\section{Results and discussion}

Paclobutrazol concentraTION. The three bedding plant species 
used were selected to represent a range of plant growth regulator sensitivity. Lateral length in scaevola was responsive to low concentrations of paclobutrazol applied as a liner dip (Fig. 1). Plants dipped in a concentration of $2 \mathrm{mg} \cdot \mathrm{L}^{-1}$ were $44 \%$ smaller compared with the untreated plants. In contrast, petunia and impatiens plants were only $11 \%$ and $26 \%$ smaller, respectively, than the untreated controls following a liner dip at $2 \mathrm{mg} \cdot \mathrm{L}^{-1}$ (Fig. 2). Petunia and impatiens that were treated with 16 $\mathrm{mg} \cdot \mathrm{L}^{-1}$ paclobutrazol were $46 \%$ and $33 \%$ smaller, respectively, when compared with the untreated controls. In these experiments, paclobutrazol liner dips had greater activity on scaevola than petunia or impatiens, which is consistent with data reported by Blanchard and Runkle (2007). The responses of these three bedding plant crops show response curves that are indicative of an effective growth regulator application. Also, the responses to the liner dip concentration are similar to the responses that are observed with other plant growth regulator application techniques (Latimer and Thomas, 1998; Starman and Williams, 2000; Whipker, et al., 2000). These findings, along with those of Blanchard and Runkle (2007) and Cerveny and Barrett (2002), indicate that plant growth regulator concentration is an important variable in liner dip applications and that research is

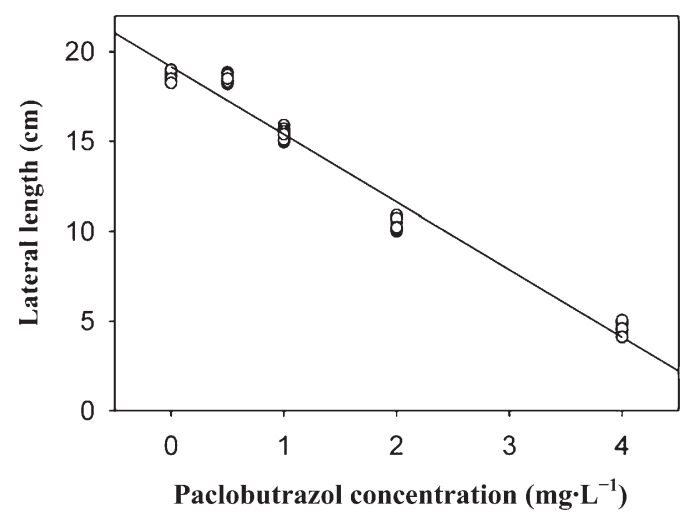

Fig. 1. Average lateral length of 'Fancy' scaevola following a liner dip application of paclobutrazol at concentrations of $0,0.5,1,2$, or $4 \mathrm{mg} \cdot \mathrm{L}^{-1}(\mathrm{ppm})$. Each point represents the average of the three longest laterals on one of the 10 individual plants treated at each concentration. Regression line was generated from the best-fit model, and each point represents an individual plant. Linear regression is significant at $P \leq 0.001$ and the regression equation is $\mathrm{Y}=19.205-3.773 \mathrm{x}$; adjusted $\mathrm{r}^{2}=0.85$ $(1 \mathrm{~cm}=0.3937$ inch $)$.

needed to identify optimum concentrations for additional crops and cultivars where the procedure may be used.

Treatment location. The paclobutrazol concentration by location interaction was not significant for petunia plant size, and the main effect of location was also not significant (Table 1). The concentration main effect was significant, and plants dipped in paclobutrazol were $14 \%$ to $28 \%$ smaller than the control plants (Table 2).

The fact that location where the liner dip was applied and the interaction with paclobutrazol concentration were not significant indicates that the facility where the liner dip is performed is not likely to be a source of variability in commercial applications of this technique. The original hypothesis that location would alter size control efficacy relied upon the belief that a significant portion of the chemical is taken up by the plant directly from the plant growth regulator solution soon after application and before the chemical binds to the organic components of the substrate. If that were true, then the transpiration rate during this period could affect the amount of chemical taken up by the plant and factors that affect transpiration rate could alter the efficacy of a liner dip. However, recent studies by Boldt (2008) revealed that little paclobutrazol is taken up within the first $24 \mathrm{~h}$ following a substrate drench application; rather, the chemical is taken up gradually over the course of several days. Boldt (2008) concluded from the results of these

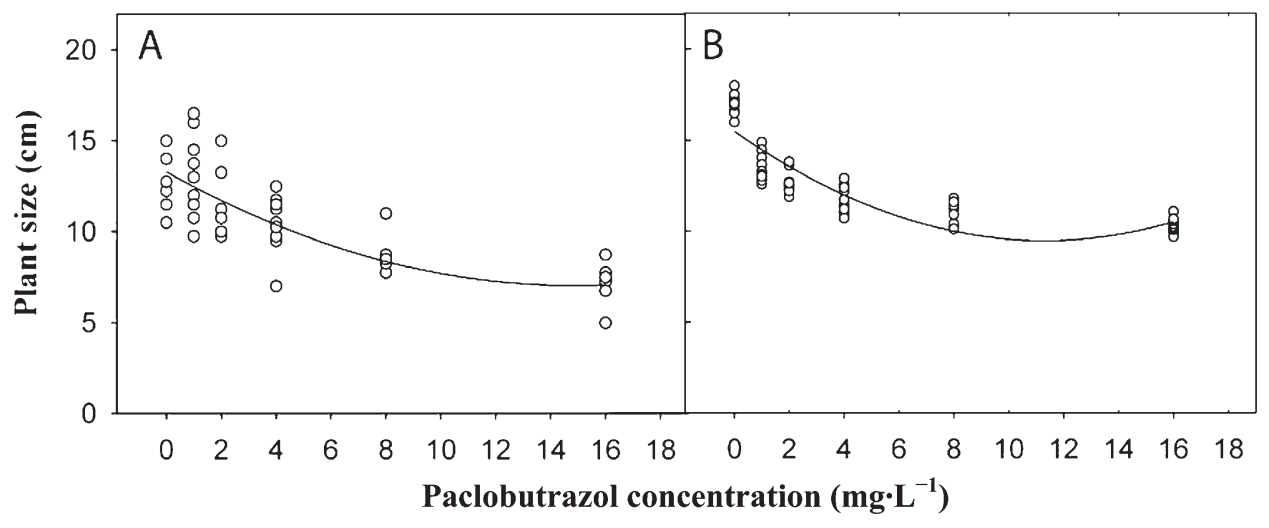

Fig. 2. Plant size of 'Suncatcher Plum' petunia (A), and 'Double Fiesta Rose' impatiens (B) following a liner dip application of paclobutrazol at concentrations of $0,2,4,8$, or $16 \mathrm{mg} \cdot \mathrm{L}^{-1}(\mathrm{ppm})$. Each point represents the size of one of the 10 plants treated at each concentration. Plant size is calculated by the formula (height + average width) $\div 2$. Regression lines were generated from the best-fit model, and each point represents an individual plant. Both quadratic regressions are significant at $P \leq 0.001$ and the regression equation for $\mathrm{A}$ is $\mathrm{Y}=0.028 \mathrm{x}^{2}-0.843 \mathrm{x}+13.301$; adjusted $\mathrm{r}^{2}=0.693$. Quadratic regression equation for $\mathrm{B}$ is $\mathrm{Y}=0.026 \mathrm{x}^{2}-0.709 \mathrm{x}+15.736$; adjusted $\mathrm{r}^{2}=0.688(1 \mathrm{~cm}=0.3937 \mathrm{inch})$. 
studies that environmental factors at the time of a paclobutrazol application to sphagnum peat-based substrate probably do not affect the size control efficacy of the application.

Substrate moisture status. Liner substrate moisture status, as measured by the percentage of container capacity, had a significant effect on petunia plant size following a paclobutrazol liner dip at $8 \mathrm{mg} \cdot \mathrm{L}^{-1}$ (Table 3). Efficacy of the liner dip increased as the substrate moisture status at the time of application decreased. At $90 \%$ and $100 \%$ of container capacity, plants were only $\approx 10 \%$ smaller than the untreated control plants. Plants that were dipped when substrate moisture status was at $50 \%$ and $20 \%$ of container capacity were $41 \%$ and $42 \%$ smaller than control plants, respectively.

Substrate moisture status AND DIP DURATION. The interaction of dip duration and substrate moisture status was not significant (Table 4). All of the paclobutrazol liner dip treatments produced plants that were smaller in size compared with the control plants. The main effect of dip duration was not significant, and there was little difference in the size of plants due to dip durations from 10 to $300 \mathrm{~s}$ (Table 4). However, it may be possible for dip duration to have a greater effect on size control efficacy of a paclobutrazol liner dip application under different conditions. Factors such as substrates with divergent hydrophilic characteristics, differing plug cell volume, or reduced depth of dip solution may allow dip duration to have a greater impact on size control efficacy.

In this experiment, the main effect of substrate moisture status had a significant effect on plant size (Table 5). The paclobutrazol dips to liners with high substrate moisture status resulted in only small suppression of final plant size, as was observed in the previous experiment.

\section{Conclusions}

The paclobutrazol liner dip yields effective size control of petunia, scaevola, and impatiens. This technique can improve efficiency of bedding plant production and the quality of the finished product. Decreasing early internode elongation allows reduced spacing and improves plant appearance in small containers. Ranwala et al. (2005) using bulb dips found that
Table 1 . Analysis of variance showing df, type 1 sum of squares (SS), and mean square (MS) for plant size [(height + average width $) \div 2$ ] of 'Suncatcher Plum' petunia following a paclobutrazol liner dip with concentrations of $0,2,4$, or 8 $\mathrm{mg} \cdot \mathrm{L}^{-1}$ (ppm) administered in one of the following locations: open-wall greenhouse, polyethylene-glazed greenhouse under $80 \%$ shade fabric, three-wall potting shed, or interior of a building under fluorescent lighting.

\begin{tabular}{lccccc}
\hline Source & df & Type I SS & MS & F value & $P>$ F \\
\hline Block & 4 & 6.94 & 1.73 & 1.09 & 0.36 \\
Paclobutrazol concn (PC) & 2 & 80.34 & 40.17 & 25.31 & $<0.001$ \\
Location (L) & 3 & 5.92 & 1.97 & 1.24 & 0.30 \\
PC $\times$ L interaction & 4 & 12.19 & 3.05 & 1.92 & 0.11 \\
\hline
\end{tabular}

Table 2. The main effects of location (A) and paclobutrazol concentration (B) on plant size of 'Suncatcher Plum' petunia following a paclobutrazol liner dip treatment at $0,2,4$, or $8 \mathrm{mg} \cdot \mathrm{L}^{-1}(\mathrm{ppm})$ administered in an open-wall greenhouse, polyethylene-glazed greenhouse under $\mathbf{8 0} \%$ shade fabric, three-wall potting shed, or interior of a building under fluorescent lighting.

\begin{tabular}{|c|c|}
\hline \multicolumn{2}{|c|}{ A } \\
\hline Location & Plant size $(\mathrm{cm})^{\mathrm{z}}$ \\
\hline Open-wall greenhouse & $12.9 \mathrm{a}^{\mathrm{y}}$ \\
\hline Greenhouse ( $80 \%$ shadecloth) & $13.1 \mathrm{a}$ \\
\hline Three-wall potting shed & $13.1 \mathrm{a}$ \\
\hline Building interior & $13.0 \mathrm{a}$ \\
\hline \multicolumn{2}{|c|}{ B } \\
\hline Paclobutrazol concn $\left(\mathrm{mg} \cdot \mathrm{L}^{-1}\right)$ & Plant size $(\mathrm{cm})$ \\
\hline 0.0 & $16.3 \mathrm{a}$ \\
\hline 2.0 & $14.1 \mathrm{~b}$ \\
\hline 4.0 & $13.3 \mathrm{c}$ \\
\hline 8.0 & $11.7 \mathrm{~d}$ \\
\hline
\end{tabular}

${ }^{2}$ Calculated by the formula (height + average width) $\div 2 ; 1 \mathrm{~cm}=0.3937$ inch.

${ }^{y}$ Means within section (A or B) followed by different letters are significantly different by Waller-Duncan K-ratio $t$ test at $P \leq 0.05$

Table 3. The effect of substrate moisture status on plant size of 'Suncatcher Plum' petunia following a paclobutrazol liner dip at $8 \mathrm{mg} \cdot \mathrm{L}^{-1}(\mathrm{ppm})$ with substrate moisture status at $100 \%, 90 \%, 80 \%, 70 \%, 50 \%$, or $20 \%$ of container capacity. A control group dipped in plain water at $\mathbf{5 0 \%}$ of container capacity is included.

\begin{tabular}{lcc}
\hline $\begin{array}{l}\text { Substrate moisture status } \\
(\% \text { container capacity })^{\mathrm{z}}\end{array}$ & $\begin{array}{c}\text { Paclobutrazol } \\
\text { concn }\left(\mathbf{m g} \cdot \mathbf{L}^{-\mathbf{1}}\right)\end{array}$ & $\begin{array}{c}\text { Plant } \\
\text { size }(\mathbf{c m})^{\mathrm{y}}\end{array}$ \\
\hline 50 & 0.0 & $13.7 \mathrm{a}^{\mathrm{x}}$ \\
100 & 8.0 & $12.2 \mathrm{~b}$ \\
90 & 8.0 & $12.5 \mathrm{~b}$ \\
80 & 8.0 & $10.3 \mathrm{c}$ \\
70 & 8.0 & $9.6 \mathrm{c}$ \\
50 & 8.0 & $8.1 \mathrm{~d}$ \\
20 & 8.0 & $7.9 \mathrm{~d}$ \\
\hline
\end{tabular}

${ }^{\mathrm{z}}$ Calculated by the formula (weight of the tray of 10 cells - average air-dried weight for a tray of 10 cells) $\div$ container capacity $\times 100$

${ }^{\mathrm{y}}$ Calculated by the formula (height + average width) $\div 2 ; 1 \mathrm{~cm}=0.3937$ inch

${ }^{x}$ Within-column means followed by different letters are significantly different by Waller-Duncan K-ratio $t$ test at $P \leq 0.05$.

Table 4. Analysis of variance showing df, type 1 sum of squares (SS), and mean square (MS) for plant size [(height + average width $) \div 2$ ] of 'Suncatcher Plum' petunia following a paclobutrazol liner dip treatment with substrate moisture status of $100 \%, 75 \%$, or $50 \%$ of water holding capacity and dip durations of $10,30,120$, or $300 \mathrm{~s}$.

\begin{tabular}{lccrrc}
\hline Source & df & Type I SS & MS & F value & $P>$ F \\
\hline Block & 4 & 4.97 & 1.24 & 0.49 & 0.74 \\
Substrate moisture status (SMS) & 2 & 363.87 & 181.93 & 71.88 & $<0.001$ \\
Dip duration (DD) & 3 & 17.37 & 5.79 & 2.29 & 0.08 \\
SMS $\times$ DD interaction & 6 & 14.60 & 2.43 & 0.96 & 0.45 \\
\hline
\end{tabular}


Table 5. The main effects of dip duration (A) and substrate moisture status (B) on plant size of 'Suncatcher Plum' petunia following a paclobutrazol liner dip at $8 \mathrm{mg} \cdot \mathrm{L}^{-1}(\mathrm{ppm})$ with substrate moisture status of $100 \%, 75 \%$, or $50 \%$ of water holding capacity and dip durations of $10,30,120$, or $300 \mathrm{~s}$. A control group dipped in plain water for $30 \mathrm{~s}$ with substrate moisture status of $\mathbf{5 0 \%}$ is included.

\begin{tabular}{|c|c|c|}
\hline \multicolumn{3}{|c|}{ A } \\
\hline Dip duration (s) & $\begin{array}{l}\text { Paclobutrazol concn } \\
\left(\mathrm{mg} \cdot \mathrm{L}^{-1}\right)\end{array}$ & $\begin{array}{c}\text { Plant size } \\
(\mathrm{cm})^{\mathrm{z}} \\
\end{array}$ \\
\hline 30 & 0.0 & $14.2 \mathrm{a}^{\mathrm{y}}$ \\
\hline 10 & 8.0 & $11.6 \mathrm{~b}$ \\
\hline 30 & 8.0 & $11.5 \mathrm{~b}$ \\
\hline 120 & 8.0 & $10.8 \mathrm{~b}$ \\
\hline 300 & 8.0 & $10.8 \mathrm{~b}$ \\
\hline \multicolumn{3}{|c|}{ B } \\
\hline $\begin{array}{l}\text { Substrate moisture status } \\
(\% \text { container capacity })^{\mathrm{x}}\end{array}$ & $\begin{array}{c}\text { Paclobutrazol concn } \\
\left(\mathrm{mg} \cdot \mathrm{L}^{-1}\right)\end{array}$ & $\begin{array}{l}\text { Plant size } \\
(\mathrm{cm})\end{array}$ \\
\hline 50 & 0.0 & $14.2 \mathrm{a}$ \\
\hline 100 & 8.0 & $12.9 \mathrm{~b}$ \\
\hline 75 & 8.0 & $11.8 \mathrm{c}$ \\
\hline 50 & 8.0 & $8.8 \mathrm{~d}$ \\
\hline
\end{tabular}

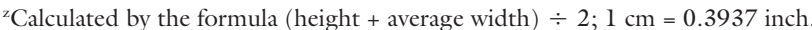

${ }^{y}$ Means within each section (A or B) followed by different letters are significantly different by Waller-Duncan K-ratio $t$ test at $P \leq 0.05$.

${ }^{\mathrm{x}}$ Calculated by the formula (weight of the tray of 10 cells - average air-dried weight for a tray of 10 cells) $\div$ container capacity $\times 100$.

multiple dip events in the same solution cause no decrease in size control efficacy, which indicates that a liner dip solution can be used to treat multiple trays, improving chemical use efficiency.

This research indicates that the specific protocol for liner dips is flexible, thus it can be adapted to a wide variety of commercial production settings. The treatment location does not alter the size control achieved; therefore the application could be conducted in any suitable location, from the greenhouse bench to the potting shed. In these experiments, there was no difference in size control achieved when plugs were dipped with substrate moisture status of $20 \%$ to $50 \%$ of container capacity or with dip durations of 10 to $300 \mathrm{~s}$.

The actual volume of solution taken up was not recorded in these experiments, but it can be reasonably concluded that the substrate must have sufficient water holding capacity available at the time of the dip treatment to allow absorption of the plant growth regulator solution. At substrate moisture status of $20 \%$ and $50 \%$, very similar size control was achieved. It can be assumed that the cells at $20 \%$ of container capacity should have taken up a greater volume of solution thus a greater quantity of the a.i. The lack of difference in size control achieved indicates that small variations in a.i. uptake do not impact size control to a significant extent. This indicates that specific measurement of substrate moisture status would not be necessary for commercial applications. Also, as a plug tray dries down, the cells around the edge of the tray generally dry faster than those in the interior. Given the consistency of the size control achieved with substrate moisture status of $20 \%$ to $50 \%$ of container capacity, this variation in moisture status across a plug tray should not alter the size control achieved.

The liner dip procedure offers bedding plant growers an efficient and effective size control option. This technique allows many plants to be treated with minimal labor and a limited amount of the plant growth regulator. However, additional research is needed to determine the substrate moisture status and dip duration necessary for consistent size control in more varied systems.

\section{Literature cited}

Barrett, J.E. and C.A. Bartuska. 1982. PP333 effects on stem elongation dependant on site of application. HortScience 17:737-738.

Barrett, J.E. and T.A. Nell. 1992. Efficacy of paclobutrazol and uniconazole on four bedding plant species. HortScience 27: 896-897.
Barrett, J.E., R.K. Schoellhorn, C.A. Bartuska, D.G. Clark, and T.A. Nell. 2003. Uniconazole application to container substrate surface prior to planting bedding plants. HortScience 38:169-172.

Blanchard, M.G. and E.S. Runkle. 2007. Dipping bedding plant liners in paclobutrazol or uniconazole inhibits subsequent stem extension. HortTechnology 17: 178-182.

Boldt, J.L. 2008. Whole plant response of chrysanthemum to paclobutrazol, chlormequat chloride, and (s)-abscisic acid as a function of exposure time using a splitroot system. MS Thesis, Univ. Florida, Gainesville.

Cerveny, C.B. and J.E. Barrett. 2002. Limiting variability in sumagic liner dip treatments. Southern Nursery Assn. Res. Conf. Proc. 50:378-382.

Gent, M.P.N. 2004. Efficacy and persistence of paclobutrazol applied to rooted cuttings of rhododendron before transplant. HortScience 39:105-109.

Gibson, J. and J. Groninger. 2006. Controlling perennials with PGRs. Ornamental Outlook 15:24-26.

Latimer, J.G. and P.A. Thomas. 1998. Screening bedding plants for response to plant growth regulators. HortScience 33: 446-447.

Magnitskiy, S.V., C.C. Pasian, M.A. Bennett, and J.E. Metzger. 2006. Controlling plug height of verbena, celosia, and pansy by treating seeds with paclobutrazol. HortScience 41:158-161.

Million, J.B., J.E. Barrett, T.A. Nell, and D.G. Clark. 1999. Inhibiting growth of flowering crops with ancymidol and paclobutrazol in subirrigation water. HortScience 34:1103-1105.

Ranwala, N.K.D., A.P. Ranwala, and W.B. Miller. 2005. Paclobutrazol and uniconazole solutions maintain efficacy after multiple lily bulb dip events. HortTechnology 15:551-553.

Schnelle, R. and J. Barrett. 2006. Reducing PGR liner dip variables. Greenhouse Product News 16:70-72.

Schnelle, R., C. Cerveny, and J. Barrett. 2005. Factors affecting PGR liner dips. Greenhouse Product News 15:20-25.

Starman, T.W. and M.S. Williams. 2000. Growth retardants affect growth and flowering of scaevola. HortScience 35: 36-38.

Whipker, B.E., B. Holloman, and C.D. Price (eds.). 2000. 2000-2001 NCCFGA handbook. North Carolina Commercial Flower Growers’ Assn., Raleigh, NC. 